\title{
Diffuse Large B-Cell Lymphoma by Ann Arbor Stage
}

National Cancer Institute

\section{Source}

National Cancer Institute. Diffuse Large B-Cell Lymphoma by Ann Arbor Stage. NCI

Thesaurus. Code C141254.

An anatomic stage for diffuse large B-cell lymphoma based on the Ann Arbor

classification criteria. 